This item was submitted to Loughborough's Research Repository by the author.

Items in Figshare are protected by copyright, with all rights reserved, unless otherwise indicated.

\title{
La moisissure et la bactérie: deconstructing the fable of the discovery of penicillin by Ernest Duchesne
}

PLEASE CITE THE PUBLISHED VERSION

http://dx.doi.org/10.1016/j.endeavour.2016.07.005

PUBLISHER

(C) Elsevier

VERSION

AM (Accepted Manuscript)

\section{PUBLISHER STATEMENT}

This work is made available according to the conditions of the Creative Commons Attribution-NonCommercialNoDerivatives 4.0 International (CC BY-NC-ND 4.0) licence. Full details of this licence are available at: https://creativecommons.org/licenses/by-nc-nd/4.0/

\section{LICENCE}

CC BY-NC-ND 4.0

\section{REPOSITORY RECORD}

Shama, Gilbert. 2016. "La Moisissure Et La Bactérie: Deconstructing the Fable of the Discovery of Penicillin by Ernest Duchesne”. figshare. https://hdl.handle.net/2134/21810. 


\section{La Moisissure et la Bactérie: Deconstructing the Fable of the Discovery of Penicillin by Ernest Duchesne}

Gilbert Shama

Department of Chemical Engineering.

Loughborough University

Loughborough

Leicestershire, LE11 3TU, UK.

+441509222514

G.Shama@Lboro.ac.uk

Abstract: Ernest Duchesne (1874-1912) completed his thesis on microbial antagonism in 1897 in Lyon. His work lay unknown for fifty years, but on being brought to light led to his being credited with having discovered penicillin prior to Alexander Fleming. The claims surrounding Duchesne are examined here both from the strictly microbiological perspective, and also for what they reveal about how the process of discovery is frequently misconstrued. The combined weight of evidence presented here militates strongly against the possibility that the species of Penicillium that Duchesne worked with produced penicillin.

Keywords: Ernest Duchesne, Penicillin, Alexander Fleming, Penicillium 


\section{Introduction}

Following the appearance of an article on penicillin in The Times of London in the summer of 1942, ${ }^{1}$ Almroth Wright, head of the inoculation department at St Mary’s Hospital in Paddington, wrote to the editor concerning a colleague of his-a certain Alexander Fleming. In his letter, Wright pointed out that the newspaper had "refrained from putting the laurel wreath around anybody's brow for [penicillin's] discovery" and that "on the principle of palmam qui meruit ferat (let him bear the palm who has earned it) it should be decreed to Professor Fleming.”2 A number of commentators over the seventy years or so that have elapsed since the publication of this letter have sought to remove-snatch even-the wreath from Alexander Fleming's brow and award it elsewhere. This article addresses attempts of this sort made by those who have proposed that the rightful recipient should in fact be Ernest Duchesne.

Duchesne (1874-1912) undertook research on microbial antagonism in Lyon and published his thesis on the subject in 1897 whereupon he joined the French army as a physician. The following examines claims relating to Duchesne from two perspectives; that based on an analysis of the details of Duchesne's experiments as set down in his thesis, and also from the wider perspective of what making a scientific discovery actually entails. The former are set alongside the most recent findings relating both to the taxonomy of the genus Penicillium and to the nature of metabolites elaborated by the penicillia. Also included are considerations that relate to the species of animal—guinea pigs—with which Duchesne conducted his in vivo experiments, as these enable a definitive judgement to be made regarding whether or not he was working with crude penicillin preparations.

\footnotetext{
1 “Penicillium,” The Times, August 27, 1942, 5.

2 Almroth Wright, "Letter to the Editor,” The Times, August 31, 1942, 5.
} 
Consideration of what constitutes a scientific discovery is made with specific reference to the work on this subject by that philosopher of science, Thomas Kuhn. Briefly, Kuhn's definition a discovery involves both recognizing that something is and, most crucially, what it is. ${ }^{3}$ Reference to these criteria shall be applied throughout this article where appropriate.

Does it matter who is credited with the discovery of penicillin? It is surely sufficient to acknowledge that the antibiotic has saved countless lives. The answer to this question is important because accounts of the discovery of penicillin are used in a number of ways and for different purposes. Many such accounts distort and misrepresent the actual process by which penicillin came to be made available as a chemotherapeutic agent, and by extension, the very process of discovery itself. Such misrepresentations are not necessarily without wider consequences, as the examples given below show.

In a biology textbook aimed at fifteen- to sixteen-year-old British schoolchildren, the authors inform their readers that "Alexander [Fleming] was rather careless," ${ }^{4}$ when in fact, as will be demonstrated below, nothing could be further from the truth: he was rather the epitome of the meticulous researcher who deliberately broke the rules in order to court the consequences. Robert Bud identifies another misleading pronouncement, this time in a newspaper. ${ }^{5}$ A columnist in London's Evening Standard criticized the massive expenditure on medical research, claiming that most drugs were discovered by accident. To support his

\footnotetext{
${ }^{3}$ Thomas S. Kuhn, “Historical Structure of Scientific Discovery,” Science 136 (1962): 760-
} 64.

${ }^{4}$ Ann Fullick, Margaret Cross, and Faye Meek, AQA Certificate in Biology (iGCSE) (Cheltenham: Nelson Thornes, 2011), 35.

${ }^{5}$ Robert Bud, "Penicillin and the New Elizabethans," British Journal for the History of Science 31 (1998): 305-33. 
argument he simply quoted the word "penicillin.” Finally, in a debate in the British House of Commons in November 1997 on college fees at the universities of Oxford and Cambridge, Evan Harris, a Liberal Democrat Member of Parliament, proclaimed, “penicillin was discovered in an Oxford laboratory." ${ }^{6}$ It is surely important to ensure that schoolchildren, the public at large, and ultimately policymakers, should have a true appreciation and understanding of how scientific discoveries are made.

\section{The Development of Penicillin as a Chemotherapeutic Agent}

The events following the celebrated observation made by Alexander Fleming in the late summer of 1928 in which he witnessed the bacteriolytic action of a mold belonging to the genus Penicillium toward Staphylococcus aureus are generally well known, and have been related not only in the biographies of Fleming (see, for example, Gwyn Macfarlane’s 1985

life $)^{7}$ but also in those of the principal characters who were subsequently instrumental in developing penicillin as a chemotherapeutic agent. Notwithstanding, I will briefly set them out here to provide a point of reference.

Having isolated the mold, Fleming cultured it in broths but failed to purify the active principle (i.e. the penicillin) from such liquid cultures. The general consensus is that as a consequence of this he totally lost interest in penicillin and conducted no further work on it, but evidence has been brought to light that in fact he continued to maintain an interest in

\footnotetext{
${ }^{6}$ Hansard, “Oxford and Cambridge College Fees,” accessed May 12, 2016, http://hansard.millbanksystems.com/commons/1997/nov/19/oxford-and-cambridge-collegefees\#S6CV0301P0_19971119_HOC_79.

${ }^{7}$ Gwyn Macfarlane, Alexander Fleming: The Man and the Myth (Oxford: Oxford University Press, 1985).
} 
penicillin throughout the 1930s. ${ }^{8}$ Nor did Fleming refrain from mentioning his work on penicillin to others. C. G. Paine attended medical school at St Mary’s in London and received lectures from Fleming. ${ }^{9}$ He subsequently obtained a post at the Sheffield Royal Infirmary where he maintained contact with Fleming and obtained a culture of Penicillium from him, which he used at the end of 1930 and beginning of 1931 to treat infections-primarily of the eye-with crude filtrates.

It was a decade after Fleming’s original observation when the pathologist Howard Florey and his colleagues at the Sir William Dunn School of Pathology at the University of Oxford decided to investigate the phenomenon of microbial antagonism. Of the handful of candidate substances they had shortlisted for potential further study, they happened to start with penicillin. Milton Wainwright and Harold T. Swan put forward convincing evidence in 1986 that Paine may have acted in what was in effect a "go between" for Fleming and Florey. ${ }^{10}$ Prior to taking up his post at Oxford, Florey had been at Sheffield at the same time as Paine and was aware of his attempts to treat infections using crude filtrates. The Oxford team made rapid progress with culturing the mold on what might be termed the "pilot scale" and in purifying the penicillin, which led to their demonstration of penicillin's therapeutic potential.

Instrumental in solving the problem of extracting penicillin from crude mold brothsa feat that had defeated Fleming and his assistants—-was the participation of the German émigré biochemist, Ernst Chain. The group’s successes were rapidly capitalized upon and

\footnotetext{
${ }^{8}$ Milton Wainwright, “Fleming’s Unfinished,” Perspectives in Biology and Medicine 45 (2002): 529-38.

${ }^{9}$ Milton Wainwright and Harold T. Swan, “C. G. Paine and the Earliest Surviving Clinical Records of Penicillin Therapy,” Medical History 30 (1986): 42-56.

${ }^{10}$ Ibid.
} 
directly gave rise to the massive Anglo-American program for the bulk production of penicillin during the Second World War, which involved both academic researchers and the pharmaceutical industry. In 1945, Fleming, Florey, and Chain were awarded the Nobel Prize in Physiology or Medicine for "the discovery of penicillin and its curative effect in various infectious diseases."11

\section{The Work of Ernest Duchesne}

Before considering the evidence for the claims surrounding Duchesne and penicillin in greater detail it will prove useful to provide a short biography of his life and a brief description of his work. Ernest Duchesne was born in Paris on May 30, 1874, the son of a chemical engineer who owned a tannery. ${ }^{12}$ On completing his secondary school studies he gained admittance to the École du Service de Santé Militaire in Lyon in 1894. In 1896 he began his research under the supervision of Professor Gabriel Roux who also held the post of Director of the Municipal Office of Hygiene for Lyon.

Roux had been the author, in 1892, of a textbook on the microbiological analysis of water. ${ }^{13}$ He had observed, and become intrigued by, the fact that whereas mold spores were found in abundance in the air, they were absent from both tap water and fountain water, although they could be induced to grow in distilled water. He wondered whether such waters contained certain microorganisms that somehow prevented the growth of molds and set

11 “The Nobel Prize in Physiology or Medicine 1945,” Nobelprize.org, accessed May 22, 2016, https://www.nobelprize.org/nobel_prizes/medicine/laureates/1945/.

12 Jean Pouillard, "Une découverte oubliée: la thèse de médecine du docteur Ernest Duchesne (1874-1912),” Historie des Sciences Médicales 36 (2002): 11-20.

${ }^{13}$ Gabriel Roux, Precis d'Analyse Microbiologique des Eaux (Paris: J.-B. Ballière et fils, 1892). 
Duchesne to work on this topic. Duchesne defined this problem explicitly in evolutionary terms. He referred directly to Darwin and his theory of evolution by natural selection in the first line of the opening chapter in his thesis. ${ }^{14}$

Darwin’s magnum opus On the Origin of Species was published in 1859. Clémence Royer's French translation appeared in 1862 as De l'Origine des Espèces ou des Lois du Progrès chez les Êtres Organisés. She rendered Darwin’s English phrase “struggle for life”the title of chapter three-as “concurrence vitale”. ${ }^{15}$ That term appeared in Duchesne's thesis title: Concurrence Vitale chez les Microorganismes: Antagonisme entre les Moisissures et les Microbes (The Struggle for Life amongst Microorganisms: Antagonism between Molds and Bacteria; figure 1). He observed in his introduction that the question of "la concurrence vitale" had only been studied closely in plants and animals. His plan to examine vital struggle in microorganisms had the potential to uncover valuable medical applications. ${ }^{16}$

${ }^{14}$ Ernest Duchesne, Contribution à l'Étude de la Concurrence Vitale chez les Microorganismes: Antagonisme entre les Moisissures et les Microbes (Lyon: Alexandre Rey, 1897), 9.

${ }^{15}$ Darwin, who had a testy relationship with Royer, turned to Jean-Jacques Moulinié for a new French translation in 1873 based on the sixth and final edition of the Origin. Moulinié retitled chapter three “De la Lutte pour L'existance” and otherwise eliminated the phrase “concurrence vitale.” Royer’s translation remained popular, however. See Joy Harvey, ““Strangers to Each Other’: Male and Female Relationships in the Life and Work of Clémence Royer,” in Uneasy Careers and Intimate Lives: Women in Science, 1789-1979, eds. Pnina G. Abir-Am and Dorinda Outram (New Brunswick: Rutgers University Press, 1987), 147-171; and Bernard Lightman, “Scientific Naturalists and their Language Games,” History of Science 53 (2015): 395-416

${ }^{16}$ Duchesne, Contribution (ref. 14), 7. 
Fig. 1. Title page of Duchesne’s thesis.

This, however, was not the first use of the term in a microbiological context in French. In his bibliography to his thesis, Duchesne referred to work by the pathologist Albert Charrin, who published an article on "La concurrence vitale en bactériologie” in 1892 and the following year, in collaboration with a younger colleague, Arsène d'Arsonval, a paper on the “concurrence vitale” between the pyocyanic bacillus and beer yeast. ${ }^{17}$ Duchesne also acknowledged the influence of the work of Louis Pasteur. In their 1877 study of anthrax, Pasteur and Jules François Joubert described the inhibitory effect of certain aerobic bacteria on the anthrax bacillus stating that "among inferior organisms [i.e. microorganisms] more so than in the higher animals and plants, life prevents life" ("la vie empêche la vie"). ${ }^{18}$ Jacques Archimbaud views Duchesne's work as being situated at the "confluence” of these two themes, and considers that of Darwin's to be the more philosophical of the two. ${ }^{19}$

Duchesne worked with three species of microorganism. The two species of bacteria he employed are somewhat easier to determine the true identity of than the species of mold referred to in his thesis. The former were the "bacille d'Eberth" and Bacterium coli communis. The first of these is Eberth's typhoid bacillus, now referred to as Salmonella enterica serovar Typhimurium, and the second is Escherichia coli. The third organism Duchesne employed was a mold that he referred to as belonging to the species Penicillium glaucum. Pouillard has

${ }^{17}$ Ibid., 55.

${ }^{18}$ Louis Pasteur and Jules F. Joubert, “Charbon et septicémie,” Comptes Rendus de l'Académie des Sciences 85 (1877): 101-15.

${ }^{19}$ Jacques Archimbaud, “Un précurseur de la découverte de la pénicilline: Le professeur Gabriel Roux,” Bulletin Historique at Scientifique de l'Auvergne 88 (1976): 111-31. 
noted that, throughout his thesis, Duchesne refers to the organism as "Penicillum." ${ }^{20}$ Setting orthography aside, determining the precise identity of the mold that Duchesne worked with is fraught with difficulties and is considered in further detail below.

In his first experiments, Duchesne showed conclusively that the mold was not only able to survive in sterile water but actually to increase in number, whereas in tap water or water from a public fountain the number of mold spores decreased while the number of bacteria present showed a corresponding increase. He summarized these experiments by stating that in the struggle for existence the advantage had clearly been in favor of the bacteria, but he wondered whether there could be circumstances where the mold could triumph over the bacteria, or at least neutralize its harmful effects. He demonstrated this by conducting experiments with guinea pigs. He injected one animal intraperitoneally with $E$. coli and reported that it died the same night. Another, injected with S. typhi, died within twenty-four hours. However, when he co-injected mixtures of $P$. glaucum with either of the two bacteria, the two test animals survived. ${ }^{21}$

Finally, in the conclusion to his thesis, he speculated that his findings could lead to both prophylactic and therapeutic applications. His work was well received by his examiners, and on graduating in 1897 he undertook an internship at the Val-de-Grâce Hospital in Paris. Toward the end of 1898, he was appointed physician to the $2^{\text {nd }}$ Regiment of Hussars based in Senlis. He married in 1901, but his wife died two years later of what was possibly tuberculosis. He himself became ill with what may also have been tuberculosis in 1904, and

\footnotetext{
${ }^{20}$ Pouillard, “Une découverte oubliée” (ref. 12). It should be pointed out that Pouillard himself makes a rather significant spelling mistake in referring to Alexander Fleming throughout his otherwise informative article as “A. Flemming”!

${ }^{21}$ Duchesne, Contribution (ref. 14), 37-40.
} 
was placed on permanent sick leave in 1907. He spent the last years of his life at various sanatoria in the South of France and in Switzerland before dying on $30^{\text {th }}$ April $1912{ }^{22}$

\section{Ernest Duchesne and Penicillin}

Credit for bringing Duchesne’s work to light is generally attributed to Justin Godart, who in February 1949 made a presentation entitled "Le précurseur français de l'action 'antibiotique' du pénicillium" (The French forerunner of the antibiotic action of Penicillium) before the Academie Nationale de Médecine. ${ }^{23}$ Godart, however, was certainly not the first to cite Duchesne's thesis. Pouillard draws attention to a review published in 1946, which refers to Duchesne's work. ${ }^{24}$ The term "forerunner" was to reappear more than once in publications following Godart's use of this term in reference to Duchesne, but over time the claims made for Duchesne have assumed a much wider scope, and range from those that assert categorically that he discovered penicillin in or around 1896 to those that credit him with being the first to report the antagonism displayed by the penicillia toward bacteria.

These claims exist both on websites and in print. The latter include articles in learned journals, specialized textbooks dealing with antibiotics and bacterial infections, popular science and medicine books, and newspapers. Furthermore, they vary from the almost casual

\footnotetext{
${ }^{22}$ Pouillard, “Une découverte oubliée” (ref. 12)

${ }^{23}$ Justin Godart “Le précurseur français de l’action “antibiotique” du pénicillium.” Bulletin de l'Académie Nationale de Médecine 133, no. 7-8 (1949): 143-46.

${ }^{24}$ Pouillard, “Une découverte oubliée” (ref. 12); Gaston Ramon and Rémy Richou, “De l'antagonisme microbien en général et en particulier des propriétés antibiotiques et antidotiques des filtrats de culture du B. subtilis et du Penicillium notatum à l'égard de certaines bactéries pathogènes et des toxines microbiennes; conséquences pratiques et théoriques,” Le Progrès Médical 14 (July 1946): 309-17.
} 
reference, ${ }^{25}$ to those of a more polemical tone, demanding that Duchesne's discovery be acknowledged. ${ }^{26}$ Too many such claims have been made on websites to attempt to analyze them in detail, but a few examples will illustrate the point.

The French Wikipedia entry (in translation) "List of discoveries and inventions related to chance,”27 contains the following: “1928 penicillin rediscovered (well after the thesis of Ernest Duchesne) by Alexander Fleming.” In contrast, the entry on “La Pénicilline” ${ }^{28}$ states forthrightly_ —and with a precision that is not entirely justifiable — that “penicillin was discovered on 3rd September 1928 by the Briton, Alexander Fleming.” Still other websites choose instead to credit Professor Gabriel Roux (Duchesne’s supervisor for his thesis studies) with the discovery of penicillin. One such claim contains at its opening the resounding biblical quotation (in French), "Render therefore unto Caesar the things which are Caesar’s.”29

${ }^{25}$ Iza Radecka, Claire Martin, and David Hill, “The Problem of Microbial Drug Resistance,” in Novel Antimicrobial Agents and Strategies, ed. David A. Phoenix, Frederick Harris and Sarah R. Dennison (Weinheim: Wiley-VCH, 2015), 2.

${ }^{26}$ Patrice Claude, “Le découvreur de la pénicilline était francais, affirme un gentleman anglais,” Le Monde, July 18-19, 1999.

27 “Liste des découvertes et inventions liées au hazard,” Wikipedia, accessed December 12, 2015, https://fr.wikipedia.org/wiki/Liste_des_d\%C3\%A9couvertes_et_inventions_li\%C3\%A9es_au _hasard

28 “Pénicilline,” Wikipedia, accessed December 13, 2015, https://fr.wikipedia.org/wiki/Pénicilline Accessed 13.12.15

${ }^{29}$ Morgan Couturier, “Gabriel Roux a découvert l’action antibiotique de la pénicilline, 31 ans avant Fleming,” La Montagne, June 22, 2014, 
The articles in learned journals generally assume a more sober and well-considered view of Duchesne's contribution, but they are not entirely devoid of unsubstantiated claims. The historical survey of microbial antagonism by Gaston Ramon and Rémy Richou states that "Duchesne was the first to relate the antagonism of molds belonging to the genus Penicillium and bacteria.”30 Another author claims: "these facts [i.e. a summary of Duchesne’s findings] are sufficient to establish that Duchesne discovered not only the existence—-but also the mechanism—of the struggle for existence between molds and bacteria." 31 Yet another commentator writes: "We see...that the true inventors of the action of penicillin on microorganisms are Professor Roux and Dr Duchesne.”32 Turning to textbooks, in their contribution to a survey of antimicrobial agents and strategies for generating novel agents, Iza Radecka and colleagues state forthrightly and without qualification that "penicillin was first discovered by a French medical student Ernest Duchesne.”33

Similarly, in their textbook aimed at first-year chemical and bioprocessing engineering students, Ricardo Simpson and Sudkir K. Sastry claim that "according to the historical background, the person who first noticed the presence of penicillin was not

http://www.lamontagne.fr/auvergne/actualite/departement/puy-dedome/issoire/2014/06/22/gabriel-roux-a-decouvert-laction-antibiotique-de-la-penicilline-31ans-avant-fleming_11051574.html.

${ }^{30}$ Ramon and Richou, “De l'antagonisme microbien” (ref. 24), 310.

${ }^{31}$ M. Rochette “M. Fleming est-il vraiment l'inventeur de la pénicilline?” L’Information Dentaire 37 (1955): 738-39.

32 Delacroix D. Les precurseurs de la pénicilline. Le Concours Medical, 22 (1955): 2245-46. ${ }^{33}$ Radecka et al., “Microbial Drug Resistance” (ref. 25), 2. 
Alexander Fleming but the French medical student Ernest Duchesne, in 1896.”34 Likewise, Duchesne features in an ANZ Journal of Surgery article on famous discoveries by medical students. ${ }^{35}$ In his highly acclaimed book Bad Medicine, David Wootton seeks to jointly apportion credit for the discovery of penicillin—but not to Fleming and Duchesne. He writes: “Thus it would seem fair to say that [Joseph] Lister and Duchesne had both independently discovered penicillin, and had taken it somewhat further than Fleming did, and that there was nothing remarkable in Fleming's initial identification of penicillium [sic] as an antibiotic.”’36

The case of Duchesne also made national newspapers in France. The doctor and author Georges Duhamel wrote a philosophical reflection on the conditions and climate in which great discoveries took place for Le Figaro in the early 1950s. He was inspired to write the piece after having previously read the communication made by Justin Godart on Duchesne’s work mentioned above. He too reiterated Godart's assessment that Duchesne was in effect a "précurseur" of what was to follow as a result of Fleming’s work. Duhamel went on to say that the conditions and attitudes prevalent in the West and in Europe, and the Mediterranean region in particular, made it in effect the crucible for great discoveries. ${ }^{37}$

By writing for a national newspaper, Duhamel was able to promulgate the story of Duchesne much more widely than had been achieved by previous contributors to learned journals. More intriguing is the article entitled "Le découvrer de la pénicilline était francais, affirme un gentleman anglais” (The discoverer of penicillin was a Frenchman affirms an

\footnotetext{
${ }^{34}$ Ricardo Simpson and Sudkir K. Sastry, Chemical and Bioprocess Engineering: Fundamental Concepts for First-Year Students (New York: Springer; 2013), 261. ${ }^{35}$ Mark D. Stringer and Omid Ahmadi, "Famous Discoveries by Medical Students,” ANZ Journal of Surgery 79 (2009): 901-8.

${ }^{36}$ David Wootton, Bad Medicine (Oxford: Oxford University Press, 2007), 248.

${ }^{37}$ Georges Duhamel, “Conditions et climat de la découverte,” Le Figaro, July 20, 1951.
} 
English gentleman), which appeared in Le Monde in $1999 .^{38}$ The author Patrice Claude begins by imagining Alexander Fleming, the “official discoverer of penicillin,” to be turning in his grave. The titular gentleman, Richard Barry, we are told, had apparently consulted numerous articles including Duchesne's thesis in support of his claim. Aware that Duchesne died childless, Barry hoped that there might be family members-perhaps nieces or nephews-reading his article who might feel induced to contact him with further information about their relative. Failing that, he hoped that a will of Duchesne’s might exist and be brought to light. Quite what such a will might contain would be impossible to imagine....

The ways in which the achievements of scientists are celebrated and credit is awarded to them for their discoveries is the subject of an article by Janet Browne, who took as her example Charles Darwin. ${ }^{39}$ One of the themes she explored was the "material record of celebrity,” which includes visual imagery. Imagery has been used quite extensively to promulgate the story of penicillin to a wider audience. One of the means by which this has been achieved is through the issuing of postage stamps. It is not the intention to include here a complete survey of the depiction of the discovery of penicillin in philately, as this has already been ably undertaken. ${ }^{40}$ However, it is relevant to record here that the Principality of Monaco issued a postage stamp in commemoration of the one-hundredth anniversary of Ernest Duchesne’s birth in 1974.

\footnotetext{
${ }^{38}$ Claude, “Le découvreur de la penicillin” (ref. 26).

39 Janet Browne, “Commemorating Darwin,” British Journal for the History of Science 38
} (2008): 251-74.

${ }^{40}$ Étienne Jouzier, “Découverte de la pénicilline et philatélie,” Bulletin de la Société de Pharmacie de Bordeaux 141 (2002): 181-94. 
Fig. 2. Figure 2 Postage stamp commemorating the centenary of Duchesne's birth issued in 1974.

As figure 2 shows, there is no reference to penicillin and no overt claims are made. The stamp comprises simply a portrait of Duchesne set aside a drawing of the conidiophores of Penicillium. Jos Houbraken, a taxonomist specializing in the penicillia, informs me that the drawing does not enable the species of Penicillium to be determined-a fact that, as is discussed below, turns out to be quite prophetic. In 2003, the seventy-fifth anniversary of Fleming's discovery of penicillin, and possibly in an attempt to redress the balance, Monaco issued a stamp depicting Alexander Fleming bearing the caption "Discovery of penicillin in 1928.” Although the fact that websites and newspaper articles contain errors should not come as a surprise, less excusable is the somewhat offhand manner in which the textbooks and journal articles cited above misrepresent the process of discovery itself. ${ }^{41}$ This is considered further below.

\section{A (Very) Brief History of the Origins of Microbial Antagonism}

Much has been written about the therapeutic use by a number of widely different ethnic cultures in times past of a variety of substrates that had been allowed to spontaneously become moldy. ${ }^{42}$ The persistence in the use of such folk remedies to treat superficial infections would tend to suggest that they possessed, at the very least, some therapeutic benefit. Alexander Fleming was certainly not the first person to witness microbial antagonism

${ }^{41}$ For reflection on how science textbooks alter history, see Allan Franklin, "Physics Textbooks Don’t Always Tell the Truth,” Physics in Perspective 18 (2016): 3-57 ${ }^{42}$ See for example Milton Wainwright, "Molds in Ancient and More Recent Medicine,” Mycology 3 (1989): 21-23. 
in a more controlled setting, but nor was Duchesne. The review of the phenomenon of microbial antagonism conducted by the French scientists Ramon and Richou, ${ }^{43}$ mentioned above, takes as its starting point the work of Joubert and Pasteur conducted in 1877, which demonstrated that the growth of the anthrax bacillus could be inhibited by other bacteria. In an exhaustive review of antibacterial chemotherapy, George N. Rolinson cites the even earlier work of John Burdon Sanderson. ${ }^{44}$ Sanderson, a pioneering medical officer of health in London, observed in 1871 that bacteria failed to develop in media in which there was visible growth of Penicillium mold. In late 1871 and early 1872, Joseph Lister witnessed the inhibition of bacterial growth by Penicillium. Furthermore, in 1884 Lister actually treated a case of gluteal abscess by applying culture fluid from P. glaucum.

In a study of the contribution to antibiosis by the biologist Thomas Huxley, James Friday states that Huxley first took up an interest in Penicillium in $1870 .{ }^{45}$ Huxley initially conducted a study of the available literature, and then began investigations on the various growth stages of the organism. He only pursued these studies sporadically, but in 1875 he began a correspondence with the polymath physicist John Tyndall. Tyndall had been investigating light, airborne particulate matter and putrefaction. The two began sharing information about their experiments. Working with turnip infusions, Tyndall found that bacteria were inactivated in those infusions in which mold was growing abundantly. He attributed this to the Penicillium depriving the bacteria of oxygen, but Huxley, having

\footnotetext{
${ }^{43}$ Ramon and Richou, “De l'antagonisme microbien” (ref. 24).

${ }^{44}$ George N Rolinson, “From Pasteur to penicillin —-the history of antibacterial chemotherapy,” Zentralblatt für Bakteriologie, Mikrobiologie und Hygiene Serie A 267 (1988): 307-15.

45 James Friday, “A Microscopic Incident in a Monumental Struggle: Huxley and Antibiosis in 1875,” The British Journal for the History of Science 7 (1974): 61-71.
} 
repeated Tyndall's experiments, apparently disagreed with this interpretation simply stating that he (Huxley) had "verified Sanderson's results." ${ }^{46}$ Similarly, in 1874, the physician and physiologist William Roberts claimed that he "had repeatedly observed that liquids in which the Penicillium glaucum was growing luxuriantly could with difficulty be artificially infected with Bacteria."47

Scientists initiated the study of microbial antagonism in the 1870s. Moreover, as the above demonstrates, there was an element of simultaneity in such investigations. As to what might have been the motivating factors in these investigations, the development of experimental physiology and the microbiology of Pasteur raised questions and offered powerful new research methods to answer them. The appearance of Darwin's On the Origin of Species in 1859 must surely also have been key, as it was to be years later for Duchesne. It would seem to be highly unlikely that Duchesne would have been aware of any of the investigations mentioned above and carried out in Britain.

Finally, it should not be assumed that what might be thought of as the extension of the early observations of microbial antagonism discussed above was solely conducted by Fleming. In 1939, René Dubos isolated what he termed “tyrothricin” from the bacterium Bacillus brevis and which he showed had useful antibacterial properties. ${ }^{48}$ Also at this time, Selman Waksman reported on the antibacterial action of actinomycin produced by a species

\footnotetext{
${ }^{46}$ Quoted in ibid., 68.

${ }^{47}$ William Roberts, “Studies on Biogenesis,” Philosophical Transactions of the Royal Society of London 164 (1874): 457-77.

${ }^{48}$ René J. Dubos, “Studies on a Bactericidal Agent Extracted from a Soil Bacillus: I. Preparation of the Agent. Its Activity in Vitro,” The Journal of Experimental Medicine 70
} (1939): 1-10. 
of Actinomyces. ${ }^{49}$ Although both were to prove too toxic for systemic use, this period marks a turning point in the fight against infectious diseases, and Selman Waksman and Albert Schatz would eventually isolate streptomycin in 1944.

\section{Duchesne's Mold and the Taxonomy of the Penicillia}

This section considers whether the designation that Duchesne assigns to the mold he employed in his investigations-P. glaucum — is taxonomically meaningful and can be of use in establishing whether or not it produced penicillin.

A 1979 monograph on the genus Penicillium by John I. Pitt opens with the observation that "rare indeed must be the human individual who has not encountered fungi of the genus Penicillium.” ${ }^{50}$ They are of course readily visible as greenish growths on fruits, stored grain, wood, and paper. Systematic study of fungi can be dated to the era of Linnaeus, and according to the mycologists Kenneth Raper and Charles Thom, ${ }^{51}$ the earliest known illustration unmistakably representing Penicillium occurs in the work of the botanist Pierre Bulliard in 1790. Bulliard actually refers to it as "Mucor penicillatus" (figure 3). ${ }^{52}$ Heinrich Friedrich Link first applied the name "Penicillium" to a genus of fungi in 1809. Link

${ }^{49}$ Selman A. Waksman and H. Boyd Woodruff, "Bacteriostatic and Bactericidal Substances Produced by a Soil Actinomyces,” Experimental Biology and Medicine 45 (1940): 609-14.

${ }^{50}$ John I. Pitt, The Genus Penicillium and its Teleomorphic States Eupenicillium and Talaromyces (London: Academic Press, 1979), 1.

${ }^{51}$ Kenneth B. Raper and Charles Thom, Manual of the Penicillia (Baltimore: Williams and Wilkins, 1949), 4.

${ }^{52}$ Pierre Bulliard, Herbier de la France: Champignons de la France (Paris: Didot, Debure et Belin, 1790). 
described three species, including P. glaucum (figure 4). ${ }^{53}$ Later, in 1874, Oscar Brefeld published a "life history" of P. glaucum with drawings, but Kenneth B. Raper and Charles Thom point out that nowhere in Brefeld's study is the species adequately described. ${ }^{54}$ This led to the tendency to assign virtually all green molds to the species $P$. glaucum, one which came to be roundly condemned by subsequent generations of mycologists.

Fig. 3. This drawing by Pierre Bulliard is the earliest known illustration of a Penicillium (1790). “Mucor penicillatus” is shown in Fig XI. Credit: Reproduced with the kind permission of the Director and the Board of Trustees, Royal Botanic Gardens, Kew.

Fig. 4. Drawing by Heinrich Friedrich Link of Penicillium glaucum (depicted in figure 24). Source: Reproduced with the kind permission of the Director and the Board of Trustees, Royal Botanic Gardens, Kew.

In his Handbook on Moulds, Yeasts and Actinomycetes, which first appeared in $1930,{ }^{55}$ the mycologist Arthur Henrici decried the earlier literature for referring to "species" (his quotes) without an accurate determination of identity. He went on to say that "all green forms” were often referred to as $P$. glaucum, and that because this designation had been used

\footnotetext{
53 Johann Heinrich Friedrich Link “Observationes in Ordines Plantarum Naturales,” Magazin der Gessellshaft Naturforschenden Freunde Berlin 3 no. 1 (1809): 3-42.

${ }^{54}$ Oscar Brefeld, Botanische Untersuchungen uber Schimmelpilze: Die

Entwicklungsgeschichte von Penicillium (Leipzig: Arthur Felix Verlag, 1874).

${ }^{55}$ Arthur Trautwein Henrici, Molds, Yeasts, and Actinomycetes: A Handbook for Students of Bacteriology (New York: John Wiley and Sons, 1930).
} 
so indiscriminately for a wide variety of different species, it had become worthless and its use should be avoided. Nothing illustrates the fluidity in the designation of the names of species by taxonomists more than the changing identity of the mold that Fleming first isolatedsurely the most celebrated species of the entire genus. ${ }^{56}$ All the standard Fleming biographies refer to the early misidentification of Fleming's isolate made by Charles La Touche, who classified it as P. rubrum. ${ }^{57}$ Subsequently, the American mycologist Charles Thom reclassified it as P. notatum. ${ }^{58}$ Later, Robert Samson and his collaborators broadened the definition of $P$. chrysogenum to include $P$. notatum, ${ }^{59}$ a move which Jos Houbraken and his co-authors state has been widely upheld by subsequent publications on the genus. Most interesting in the current context is their claim that the correct designation of Fleming's strain should in fact be P. rubens - orthographically at least very close to La Touche’s original designation!

In a 2013 article, fungal biologist Nicholas Money inveighs against what he terms the "Linnean fantasy of a divine order throughout nature” and the "shackles of Linnaean fundamentalism.” ${ }^{60}$ Pointing to the difficulties of even defining what constitutes a fungal species, he advocates instead the digital barcoding of fungi based on DNA sequencing. This view is somewhat revolutionary and is bound to provoke controversy, but pending resolution

${ }^{56}$ Jos Houbraken, Jens C. Frisvad, and Robert A. Samson, “Fleming’s Penicillin Producing Strain Is Not Penicillium chrysogenum but P. rubens,” IMA Fungus 2 (2011): 87-95.

${ }^{57}$ Macfarlane, Alexander Fleming (ref. 7).

${ }^{58}$ Houbraken et al., "Fleming’s Penicillin Producing Strain Is Not Penicillium chrysogenum but $P$. rubens,” (ref 56).

${ }^{59}$ R. A. Samson, R. Hadlok, A. C. Stolk, “A Taxonomic Study of the Penicillium chrysogenum Series,” Antonie van Leeuwenhoek 43 (1977): 169-75.

${ }^{60}$ Nicholas P. Money, “Against the Naming of Fungi,” Fungal Biology 117 (2013): 463-65. 
of these fundamental points at issue, we are obliged to adhere to the binominal system of referring to fungal species while both acknowledging and accepting its limitations. A recent review estimates that there are currently 354 species belonging to the genus Penicillium. ${ }^{61}$ Prior to this, it had been claimed that there were eight species in the section Chrysogena, which is contained within the genus Penicillium, which produce penicillin. ${ }^{62}$

As the foregoing demonstrates, the designation " $P$. glaucum" is essentially invalid, and of no help in attempting to establish whether a strain bearing this name produces penicillin. Nowhere in Duchesne's thesis does he indicate the origin of the strain he used, and moreover, the practice of depositing microbial strains in culture collections was virtually unheard of at the time in which Duchesne undertook his work - the first culture collection having been established only in 1890 at the German University of Prague. ${ }^{63}$ There are, therefore, no prospects of being able to repeat Duchesne’s experiments.

\section{Antibacterial Compounds Produced by the Penicillia}

Once Fleming had isolated the mold that had contaminated his petri dish, he proceeded to grow it in liquid culture so that he could determine the extent of its antibacterial properties against a wider range of bacteria. To do so he had first to separate the mold biomass from the

${ }^{61}$ Jens C. Frisvad, “Taxonomy, Chemodiversity, and Chemoconsistency of Aspergillus, Penicillium, and Talaromyces Species,” Frontiers in Microbiology 5, no. 773 (2015): 1-7. 62 J. Houbraken, J. C. Frisvad, K. A. Seifert, D. P. Overy, D. M. Tuthill, J. G. Valdez, and R. A. Samson, “New Penicillin-Producing Penicillium Species and an Overview of Section Chrysogena,” Persoonia 29 (2012): 78-100.

${ }^{63}$ Lara Durães Sette, Fernando Carlos Pagnocca, and André Rodrigues “Microbial Culture Collections as Pillars for Promoting Fungal Diversity, Conservation and Exploitation,” Fungal Genetics and Biology 60 (2013): 2-8. 
broths in which the mold was cultured, and, in his own words, "for convenience and to avoid repetition of the cumbersome phrase 'mould broth filtrate' the name 'penicillin' will be used." ${ }^{64}$ An assessment of this act of Fleming's made by the botanist Jules Brunel in 1944—a time during the Second World War when media interest in penicillin was at its peak ${ }^{65}$-is worthy of consideration here. ${ }^{66}$ Brunel cites Fleming's coining of the name penicillin as the reason why Fleming, rather than any of the previous witnesses to microbial antagonism, achieved fame. But this is to misinterpret Fleming's action; it is clear that from the outset that Fleming envisaged a specific chemical entity—the what in Kuhn's usage. In an interview Fleming granted The Scotsman newspaper a decade after his original observation, he said that penicillin was "probably a quite simple chemical, and it could be made in the same way as sulphonamide.”67 Of all the individuals mentioned above (including Duchesne) who witnessed microbial antagonism, only Tyndall postulated a mechanism by which the phenomenon manifested itself. To recall, he believed — wrongly as it turned out—-that the mold was depriving the bacteria of oxygen.

It was later to emerge that the penicillins are in fact a family of compounds. This was first realized in 1943 when British and American researchers independently came up with different chemical formulae for penicillin. Further investigation revealed that the strains of

${ }^{64}$ Alexander Fleming, "On the Antibacterial Action of Cultures of a Penicillium, with Special Reference to Their Use in the Isolation of B. influenza,” The British Journal of Experimental Pathology 10 (1929): 226-36.

${ }^{65}$ Gilbert Shama, “The Role of the Media in Influencing Public Attitudes to Penicillin During World War II,” Dynamis 35 (2015): 131-52.

${ }^{66}$ Jules Brunel, “Qui a découvert la pénicilline?” Revue Canadienne de Biologie 3 (1944): 333-43.

67 “Hope of a New Drug,” The Scotsman, November 23, 1940, 5. 
Penicillium being used on either side of the Atlantic were in fact producing different penicillins; the American material was termed "Penicillin G" and the British one "Penicillin F.”68 There are in fact some half dozen naturally occurring penicillins. They differ only in the nature of the acyl side chain that is attached to the defining feature of the penicillins - the beta-lactam ring fused to a thiazolidine ring.

Penicillin belongs to a class of compounds that have traditionally been referred to as “secondary metabolites.” There are a number of definitions of just what this term signifies, but for the present purposes they can be thought of as compounds which confer certain advantages to the organisms producing them, but which are not indispensable to their function and survival as would be primary metabolites which are associated with the cell's requirement for energy and nutrients. ${ }^{69}$ In the recent literature, the new coinage "extrolite" appears to be displacing the term "secondary metabolite.” An extrolite has been defined as "an outwardly directed chemical compound produced during differentiation of a living organism.”70 An extrolite is usually excreted, but can also be accumulated in the cell wall or membrane. The molds as a group produce a huge array of extrolites. A recent estimate sets the number produced by the genus Penicillium alone as $1,338 .{ }^{71}$ Included are compounds

${ }^{68}$ John Patrick Swann, “The Search for Synthetic Penicillin during World War II,” British Journal for the History of Science 16 (1983): 154-88.

${ }^{69}$ Nancy P. Keller, Geoffrey Turner, and Joan W. Bennett, “Fungal Secondary Metabolism— From Biochemistry to Genomics,” Nature Reviews Microbiology 3 (2005): 937-47.

${ }^{70}$ Robert A. Samson and Jens C. Frisvad, Penicillium Subgenus Penicillium: New Taxonomic Schemes and Mycotoxins and Other Extrolites (Utrecht: Centraalbureau voor Schimmelcultures, 2004).

${ }^{71}$ Frisvad “Taxonomy, Chemodiversity, and Chemoconsistency of Aspergillus, Penicillium, and Talaromyces Species” (Ref 56). 
exhibiting antibacterial action as well as those that are termed "mycotoxins." The distinction between them is not always clear cut: a number of compounds over the years having potent antibacterial properties have been isolated only to prove upon further testing to be too toxic for therapeutic use.

That certain extrolites could exhibit antibacterial properties but prove toxic was brought to light in an investigation conducted toward the end of the Second World War in a study on antibiotics other than penicillin produced by the penicillia. ${ }^{72}$ This study provided data on the chemical characteristics, antibacterial potency, and toxicity of the following compounds: clavicin, penicillic acid, spinulosin, penatin, citrinin, and puberulic and puberulonic acids. The toxicity data presented in this work had been conducted using a variety of animals including mice, chicks, and guinea pigs. These investigators concluded that most of these compounds — with the possible exception of penicillic acid—were possibly too toxic for therapeutic use. Later, H. Stowar Burton of Oxford's Sir William Dunn School of Pathology published his findings on the production of antibiotics by the penicillia. ${ }^{73} \mathrm{He}$ found antibacterial substances in the culture fluids of thirteen species of Penicillium. These comprised phoenicin, expansin, mycophenolic acid, penicillic acid, and herquein. In contrast to the earlier study mentioned above, he did not conduct tests for toxicity. However, he showed that some species produced "penicillin-like substances” and that furthermore, certain species were able to produce more than one antibiotic simultaneously. ${ }^{74}$

\footnotetext{
${ }^{72}$ J. S. Kiser and J. S. Zellat, “Antibiotics Other than Penicillin Produced by Penicillia,” Transactions of the New York Academy of Sciences 7 (1945): 210-19.

${ }^{73}$ H. Stowar Burton, “Antibiotics from Penicillia.” The British Journal of Experimental Pathology 30 (1949): 151-58.

${ }^{74}$ Ibid., 157.
} 
Some of the duplication of effort, and confusion over the identity of antibacterial compounds studied in this period, was later unpicked by Ronald Bentley and J. W. Bennett, who cite the case of clavacin. ${ }^{75}$ This compound was first isolated by Salman Waksman in 1943, but was later obtained independently by other investigators and variously given the names claviformin, expansin, mycoin c, and penicidin. The compound in question is now referred to as "patulin" and is classified as a carcinogen. ${ }^{76}$ It has emerged that, during the Second World War, a number of covert attempts to manufacture penicillin were undertaken in Occupied Europe. ${ }^{77}$ One such attempt was made at the Botanisch Laboratorium in Utrecht, where researchers had heard about penicillin from a number of different sources-including leaflets dropped over the country by the Royal Air Force-and attempted to undertake its production using a strain of $P$. expansum. However, postwar investigations revealed that although the active substance these workers had been producing did possess some therapeutic value in treating superficial infections, it was too toxic for parenteral administration, and that in all probability it was in fact patulin. ${ }^{78}$

As mentioned above, individual species of mold are able to produce a range of secondary metabolites, including a number of antibiotics, simultaneously. The propensity of $P$. chrysogenum to do so was rigorously investigated at the genetic level in a recent study in

${ }^{75}$ Ronald Bentley and Joan W. Bennett, "What is an antibiotic? Revisited,” Advances in Applied Microbiology 52 (2003): 303-31.

${ }^{76}$ J. L. McCallum, R. Tsao, T. Zhou, "Factors Affecting Patulin Production by Penicillium expansum,” Journal of Food Protection 65 (2002): 1937-42.

${ }^{77}$ Gilbert Shama, “Zones of Inhibition? The Transfer of Information Relating to Penicillin in Europe during World War II.” Advances in Applied Microbiology 69 (2009): 133-58.

${ }^{78}$ Combined Intelligence Objectives Sub-Committee (CIOS), Dutch Scientific Institutions in Utrecht and Amsterdam, item no. 24, file no, XXXI-17. London: HMSO; 1945. 
which strains isolated from the environment (including Fleming's strain and a highly productive one isolated during the Second World War in Peoria, Illinois)—and referred to as “wild types”-were compared with industrially employed strains that had been subject to intensive campaigns of mutagenesis and selection since the early 1940s. ${ }^{79}$ Although such campaigns had led to enormous increases in the yields of penicillin produced, the researchers established that the impact of such strain development programs was to drastically reduce the number of extrolites produced compared to that of the wild-type "parent" strains. The factors influencing the constituents of the "cocktail” of antibacterial compounds produced by wildtype isolates would be those of temperature, $\mathrm{pH}$, and composition of the growth medium.

\section{Penicillin Toxicity Tests on Animals}

In experiments carried out during the Second World War on the treatment of gas gangrene in guinea pigs with penicillin, researchers noted that all the animals died without showing symptoms of gas gangrene. This prompted a study of the toxicity of penicillin toward mice, rabbits, and guinea pigs. ${ }^{80}$ It was established that doses of penicillin that were tolerated by mice and rabbits resulted in the death of guinea pigs. Work carried out at Cornell University Medical College and the New York Hospital by Frank E. Cormia, George M. Lewis, and Mary E. Hopper with a large sample size of 58 guinea pigs confirmed the earlier findings of

${ }^{79}$ Oleksandr V. Salo, Marco Ries, Marnix H. Medema, Peter P. Lankhorst, Rob J. Vreeken, Roel A. L. Bovenberg, and Arnold J. M. Driessen, “Genomic Mutational Analysis of the Impact of the Classical Strain Improvement Program on $\beta$-lactam Producing Penicillium chrysogenum,” BMC Genomics 16 (2015): article 937.

${ }^{80}$ Dorothy M. Hamre, G. Rake, C. M. McKee, and H. B. MacPhillamy, “The Toxicity of Penicillin as Prepared for Clinical Use,” American Journal of Medical Sciences 206 (1943): $642-52$. 
the toxicity of penicillin towards this particular species, and identified the cause of death as damage to the adrenal gland. Furthermore, they showed that penicillin preparations of higher purity were associated with increased toxicity toward all animals. The researchers first presented their results in 1947 to the Eighth Annual Meeting of the Society for Investigative Dermatology. In the subsequent discussion at the meeting, the distinguished dermatologist Marion Sulzberger made the following observation: "If Fleming and his followers had tested penicillin for toxicity by first performing the customary toxicity assays on guinea pigs, they would have been forced to the costly error of concluding that therapeutically effective doses would be too toxic for use in human diseases. And the discovery of penicillin, one of the greatest medical advances of all time, would have been lost to mankind if the species homo had responded to penicillin injections as do the guinea pigs.”,

Although there is no record of Fleming ever having conducted tests of toxicity on animals, there is certainly something to Sulzberger's assessment. As the team at Oxford under Howard Florey began building up their production of penicillin, they undertook toxicity tests using mice, rats, cats, and rabbits. ${ }^{82}$ The absence of untoward effects in these animal species gave them the confidence to progress to in vivo studies. The first experiment involving bacterially infected animals that Howard Florey and his colleagues conducted on May 25, 1940, and which was to definitively reveal the therapeutic potential of penicillin, was performed using mice.

\section{Was Duchesne Working with Penicillin?}

\footnotetext{
${ }^{81}$ Frank E. Cormia, George M. Lewis, and Mary E. Hopper, “Toxicity of Penicillin for the Guinea Pig,” Journal of Investigative Dermatology 9 (1947): 261-67.

${ }^{82}$ Lennard Bickel, Rise Up to Life: A Biography of Howard Florey Who Gave Penicillin to the World (London: Angus and Robertson, 1972).
} 
It has occasionally proved possible to go some way toward inferring the identity of an antibiotic described in the early literature. For example, George N. Rolinson points out that Lister observed that filtrates of his Penicillium culture led to the development of abnormal morphology—something which Fleming was apparently fond of demonstrating using his culture broths. ${ }^{83}$ He deduces from this that Fleming might not have been the first to observe the effects of penicillin. However, there are no such leads in the case of Duchesne. And as was demonstrated above, it is not possible to pinpoint the species from the designation " $P$. glaucum” in order to attempt to reconstruct Duchesne’s experiments. As was also mentioned, 350 species of Penicillium are now formally recognized, only eight of which produce penicillins. Furthermore, it was pointed that a total of 1,338 extrolites produced by the genus Penicillium have been identified and characterized. By no means will all of these extrolites possess antibacterial properties. Moreover, of the portion that do, some will prove themselves to be too toxic for therapeutic purposes.

On a purely probabilistic basis, therefore, the likelihood that Duchesne was working with a penicillin-producing strain becomes vanishingly low. However, there exists one piece of evidence that rules out the possibility altogether. This lies in the species of animal that Duchesne used in his in vivo experiments: these were guinea pigs, which, as was revealed above, were discovered in the 1940s to display an extreme sensitivity to penicillin—one that could lead to their death. Yet, all of the guinea pigs that Duchesne treated with his preparations survived.

Duchesne's thesis reports that he injected the guinea pigs he used in his experiments with whole cultures of P. glaucum containing fungal mycelium in suspension in the broth,

\footnotetext{
${ }^{83}$ George N. Rolinson, "Discovery and Development of Beta Lactam Antibiotics,” in Fifty Years of Antimicrobials: Past Perspectives and Future Trends, ed. P. A. Hunter, G. K. Darby, and N. J. Russell (Cambridge: Cambridge University Press, 1995).
} 
which would have contained the extrolites produced by the mold. It is possible that the fungal mycelium may have stimulated the animals' innate defenses and this may have contributed to their survival. The fungal cell contains a number of components that have been shown to stimulate such a response. When such compounds are given in combination with antibacterial agents they are referred to as "adjuvants.” A recent review has shown that when polysaccharides from the fungal cell wall known as $\beta$-glucans are given in combination with vaccines enhanced protection is conferred. ${ }^{84}$ The above should not be interpreted as implying that the presence of fungal mycelium in the broths injected into the guinea pigs would have counteracted the directly lethal effects of penicillin had it been present, and therefore the case against Duchesne is not compromised. Rather, a possibility exists, albeit a slim one, that the mycelium may have acted in combination with antibacterial extrolites present in Duchesne's broths to supplement their effects.

\footnotetext{
${ }^{84}$ Stuart M. Levitz, Haibin Huang, Gary R. Ostroff, and Charles A. Specht, “Exploiting Fungal Cell Wall Components in Vaccines,” Seminars in Immunopathology 37 (2015): 199_ 207.
} 


\section{Discovery and its Context}

It is appropriate to examine here why Fleming's status as the discoverer of penicillin has never been fully accepted in some quarters. The answer lies in part in Fleming's own account of the circumstances leading to the discovery. In his article on penicillin he writes: "While working with staphylococcus variants a number of culture-plates were set aside on the laboratory bench and examined from time to time. In the examinations these plates were necessarily exposed to the air and they became contaminated with various microorganisms.” 85 That is, the contamination by the Penicillium mold was purely accidental, and therefore Fleming just happened to be lucky. The other important consideration is what Fleming came to reveal about himself and his work in the many talks and interviews he gave when penicillin was starting to become a household word: he admitted to "playing" with microbes. An accident is by definition an unforeseen incident, and on this basis an accident could happen to anybody. The implication of this for accidental discoveries in science is that the supposed discoverer has somehow not earned the title through protracted and painstaking investigation, but was merely graced by the good fortune of being in the right place at the right time. ${ }^{86}$ In particular, and in contrast to Duchesne, Fleming was not engaged in

${ }^{85}$ Fleming, “Antibacterial Action” (ref. 64), 226.

${ }^{86}$ For more on the role of accident in discovery, see Robert K. Merton and Elinor Barber, The Travels and Adventures of Serendipity (Princeton, N.J.: Princeton Univ. Press, 2006); and Sean Silver, “The Prehistory of Serendipity, from Bacon to Walpole,” Isis 106 (2015): 235256. 
investigating microbial antagonism. The nature of the investigations he was undertaking in the late summer of 1928 was, and remains, unknown.

Robert Root-Bernstein reveals that Fleming's laboratory notebook was of the looseleaf variety and that the pages covering the time in question are missing. ${ }^{87}$ He suggests that they were either mislaid or deliberately destroyed. He then goes on to conjecture that Fleming may have been investigating the possibility that the mold that contaminated his petri dish was producing lysozyme. In 1922, Fleming had discovered that a number of bodily fluids contain a compound able to lyse certain bacteria and he named it "lysozyme." Fleming continued working on lysozyme into the 1930s and showed that it was present in the organs and tissues of a variety of animal species. Root-Bernstein cites this as evidence that discovery is a process rather than an event. The attempts to credit Duchesne with the discovery of penicillin are most objectionable not because they seek to usurp credit from Fleming, but rather because they distort the process by which a community of researchers in the 1940s made penicillin available to humankind.

Root-Bernstein argues strongly against attaching the term "luck" to discoveries such as those made by Fleming, and refers to its use as the "palliative of the mediocre." ${ }^{88}$ He then goes on to reconstruct the context in which Fleming made his observation, drawing on the years of experience and insight which he had accumulated in his time as a bacteriologist. During the First World War, Fleming served in the military hospital located in the municipal casino in Boulogne in France and was actively engaged in treating battle casualties. During this time he even went as far as constructing a wound model to demonstrate how ineffectual chemical antiseptics were at disinfecting wounds.

\footnotetext{
${ }^{87}$ Robert S. Root-Bernstein, Discovering (Cambridge, MA: Harvard University Press, 1989). ${ }^{88}$ Ibid., 141.
} 
Root-Bernstein also sees as deeply significant the "playing” with microbes that Fleming indulged in. In particular, Fleming developed the pastime of "painting" scenes onto agar in petri dishes using bacteria of different colors as his pigments—a mother and child, a soldier in the Life Guards. As Root-Bernstein has pointed out, he had first to isolate his "palette" and then form an appreciation of the conditions under which the microorganisms (most probably both bacteria and yeasts) would develop their pigments. He streaked bacteria of different colors alongside one another-an action requiring a certain confidence and sureness of action, as the colors would have only become visible after incubation. But much more important than the physical deftness this required Root Bernstein argues, is the high probability that he would have encountered situations in which one "color" would simply not develop alongside another due to inter-bacterial or yeast-bacterial antagonism.

All this accumulated experience and knowledge must have coalesced in Fleming's mind when on that fateful summer's day in 1928 he reached out to pick up that (now celebrated) petri dish. Fleming may be viewed as being partly responsible for the misinterpretation made in certain quarters of his true contribution. There would seem to be much riding on the verb "playing" that Fleming used when giving interviews to the media. He was perhaps simply trying to make his modus operandi intelligible to an audience comprising the public at large; however, it has tended to be interpreted by some that he was simply amusing himself in the laboratory.

Is it to Fleming alone that credit should be granted for the discovery of penicillin? He observed that colonies of S. aureus in the vicinity of the Penicillium had been lysed-the that in Kuhn's terminology—and he formed the concept that the mold was producing a compound that diffused through the agar and was the cause of the bacterial lysis-the what. He examined the extrolites of molds from other genera and found that only one of these- 
belonging to the genus Penicillium—showed inhibitory effects against bacteria. ${ }^{89}$ Moreover, he attempted to isolate the active principle, that is the penicillin, and failed, but this does not detract from the fact that he had correctly interpreted what was taking place.

Isolation of penicillin from culture broths came to be achieved a decade later by Florey and his team at Oxford. In addition, as Wainwright has pointed out, Fleming, in contrast to the succession of individuals before him who had observed the phenomenon of microbial antagonism, preserved his culture of mold and freely made it available to anyone who applied to him for it. ${ }^{90}$ When the researchers at the Sir William Dunn School in Oxford decided to investigate penicillin, they actually had a culture of the Fleming strain available to them on their premises. It was this culture that was first used to produce penicillin for therapeutic purposes in both Britain and the United States and from which the chemical structure of the penicillins was elucidated. From this structural information was to emerge the concept of the "semi-synthetic penicillins," which, despite evidence of increasing bacterial resistance, remain a mainstay in combating bacterial infections today.

This article opened with the letter Almroth Wright had written to The Times newspaper in which he sought to award credit to Fleming for the discovery of penicillin. It is relevant to add here that this letter elicited a response from Robert Robinson, Waynflete Professor of Chemistry at Oxford University. ${ }^{91}$ Without seeking to deprive Fleming of his due — the laurel wreath crown—Robinson pointed out that it was Florey and his team at Oxford who had been responsible for isolating "therapeutic penicillin,” and that this act merited a bouquet, and a handsome one at that.

\footnotetext{
${ }^{89}$ Fleming, “Antibacterial Action” (ref. 64).

${ }^{90}$ Milton Wainwright, “Letter to the Editor,” New Scientist 147 (1995): 54.

${ }^{91}$ Robert Robinson, "Letter to the Editor,” The Times, September 2, 1942, 5.
} 
Fig. 5. A fifty-dollar Australian banknote depicting Howard Florey, which was in circulation from 1973 to 1995.

This sequence of events was recognized by the Nobel Committee when, in 1945, they awarded the Nobel Prize for Physiology or Medicine jointly to Fleming, Florey, and Chain. Reference was made above to the uses to which visual imagery has been put in promulgating scientific discoveries. Florey’s achievements with reference to penicillin were commemorated in his native land of Australia by the issue of a fifty-dollar banknote that was in circulation from 1973 to 1995 . Alongside his portrait is a cascade of images. These, as is discussed below, both provide an accurate depiction of the process leading to therapeutic penicillin and seek to acknowledge the contributions of others in this process. The uppermost image is a reproduction of Fleming's original petri dish—a direct allusion to the observation which initiated the process. Below this are two white mice-a reference to the in vivo experiment conducted in Oxford on May 25, 1940, with purified penicillin, which was to definitively demonstrate penicillin’s therapeutic potential. Included below, and slightly to the left of the mice, is a representation of the assay developed by the biochemist Norman Heatley for accurately determining the titre of penicillin solutions. Alongside the latter are mature colonies of penicillia on a semi-solid medium. This could possibly allude to the extensive search undertaken for strains of $P$. notatum able to produce higher yields of penicillin than Fleming's original isolate. As it happens, a strain found growing on a piece of melon in Peoria, Illinois was shown by microbiologists at the United States Department of Agriculture's Northern Regional Research Laboratories to exceed the yield of penicillin produced by the Fleming strain when grown under the much more efficient method of cultivation which is referred to as "submerged culture." The banknote also carries an image of bookshelves lined with antique tomes, and which may be taken as implying a nexus with 
knowledge that predates even Fleming's original observation and publication of his paper on penicillin of 1929. Also included are references to the lieu where Florey’s work on penicillin was undertaken: a reproduction of the inscription that appears on the lintel above the entrance to the Sir William Dunn School of Pathology. The recognition awarded to Florey by the University of Oxford in appointing him Provost of Queen’s College, Oxford in 1962 is signified by an image of the window of the College Library and of a statue from the Fellows' Garden

\section{Duchesne's Achievements}

Duchesne did succeed in conducting a competent investigation of microbial antagonismalthough this was, as has been demonstrated in reviews of the phenomenon, not the first of its kind. Many commentators have described that section his thesis where, having shown that molds in natural water sources are overcome by bacteria, he frames the question as to whether this situation might be reversed, as prophetic. There can be no doubt that Duchesne's mold strain did produce one or more antibacterial compounds. Moreover, following the in vivo experiments that he conducted, he had the foresight to predict the therapeutic potential in the phenomenon under investigation. Duchesne never published his findings, and indeed, Serge Duckett has brought to light the fact that when Gabriel Roux was seeking appointment to a Chair of Parasitology and Microbiology, he did not include in his CV Duchesne's thesis among the list of important theses that he had supervised. ${ }^{92}$

In considering the criticisms that have been leveled against Duchesne for not pursuing his findings further, Archimbaud points out that Duchesne did not possess ambitions to become a professional research scientist, but saw the act of gaining his doctorate as helping

\footnotetext{
92 Serge Ducket, “Ernest Duchesne and the Concept of Fungal Antibiotic Therapy,” The
} Lancet 354 (1999): 2068-71. 
him to pursue a career in military medicine. ${ }^{93}$ There is no evidence that Roux did not value Duchesne’s work; instead, Archimbaud paints a portrait of Roux as a man immersed in a number of truly diverse research interests that extended to anatomy, histology, zoology, botany, geology, epidemiology as well as practical aspects of hygiene. Another consideration he suggests that might have had some bearing on this matter is that, in addition to suffering from a variety of physical ailments, Roux was also prone to fits of depression. Notwithstanding such considerations, an elapse of some fifty years was to occur before Duchesne’s work was rediscovered.

\section{Les Derniers Mots}

The title of this piece is avowedly Fontainesque, and therefore it would seem fitting that the last words should be those of La Fontaine himself. They are offered here in tribute to Ernest Duchesne and the others who since the late nineteenth century observed and investigated the phenomenon of antimicrobial antagonism. They constitute advice to moisissures and bactérie everywhere (irrespective of species). They come from the fable entitled "Le Pot de Terre et le Pot de Fer," and they are; ne nous associons qu'avecque nos égaux (let us only associate with our equals).

\section{Acknowledgements}

Thanks are extended to Jos Houbraken of the CBS-KNAW Fungal Biodiversity Centre, Utrecht, The Netherlands, for his guidance of the taxonomy of the penicilla. I wish also to acknowledge the cooperation of Christopher Walton, Senior Library Officer, at the University of Loughborough Library for his help in obtaining copies of articles and images for me. The anonymous reviewers of my first draft submission made many helpful

${ }^{93}$ Archimbaud, “Un précurseur de la découverte de la penicilline” (ref. 19). 
suggestions for improving my article—-particularly that relating to adjuvants_-and I offer my thanks to them. 


\section{Figures}

Figure 1

Figure 2

Figure 3

Figure 4 
Figure 5 